Vol. 8 (4): 777-784 (2018)

\title{
CHANGE OF HUMUS STATUS IN CASES OF INTENSIVE CULTIVATED SOIL
}

\author{
Svetlana Yurevna Zorina, Lada Georgievna Sokolova* \\ *Federal State Budgetary Institution of Science Siberian Institute of Plant Physiology and Biochemistry SB RAS, 132, \\ Lermontov str., Irkutsk, 664033, Russia; \\ *Correspondence author: Lada Georgievna Sokolova, e-mail: sokolova.lada@ sifibr.irk.ru; \\ Received July, 2018; Accepted August, 2018; Published September, 2018; \\ DOI: https://doi.org/10.31407/ijees8418 \\ UOI license: http://u-o-i.org/1.01/ijees/46950646
}

\begin{abstract}
To obtain objective data on the changes in the humus status of agrogray soil under the influence of various methods of intensive agriculture, a long - term (1990-2014) field experiment was conducted in the conditions of the Baikal foreststeppe. It was revealed that regardless of the usage practice of arable land (continuous fallow, grain - fallow and grain row crop rotations), the humus content decreased. Its losses during fallowing and the studied crop rotations were correspondingly 21 and $15 \%$ of the initial content. The transformation trend of the system of humus substances in all the variants of the experiment was associated with a decrease in the carbon content in the labile (mobile fractions) and increase in the stable pool (immobile fractions). The humus depletion by the labile components with a decrease in its total content indicates the 'latent' degradation of the studied soil.
\end{abstract}

Key words: humus status; carbon pools; continuous fallow; crop rotations. 